УДК 378:373.3.011.3-051:378.4 (045)

DOI:

Любов Фенчак, кандидат педагогічних наук,доцент кафедри теорії та методики початкової освіти Мукачівського державного університету

\title{
ВПЛИВ СОЩАЛЬНО-ВИХОВНОГО СЕРЕДОВИЩА УНІВЕРСИТЕТУ НА ПРОФЕСІЙНУ ПІДГОТОВКУ МАЙБУТНІХ ФАХІВЦІВ ПОЧАТКОВОЇ ОСВІТИ
}

У статті уточнено сутність поняття сочіально-виховного середовища університету як простору для реалізації соціальної активності студентів. Досліджено вплив изього середовища на професійне становлення особистості майбутнього фахівия початкової освіти, формування його соиіальної мобільності та особистісно-професійної культури. Розглянуто особливості організації соиіально-виховного середовища під час професійної підготовки майбутніх вчителів початкової освіти, обтрунтовано його завдання та функиії.

Ключові слова: сочуіально-виховне середовище університету, фахова підготовка, майбутні вчителі початкових класів.

תim. 7.

Lyubov Fenchak, Ph.D.(Pedagogy), Associate Professor of the Theory and Methodology of Elementary Education Department Mukachevo State University

\section{THE INFLUENCE OFTHE SOCIAL-EDUCATIONAL ENVIRONMENT OFTHE UNIVERSITY ON THE PROFESSIONAL TRAINING OF FUTURE SPECIALISTS OF THE PRIMARY EDUCATION}

The essence of the concept of the social and educational environment of the university as a space for the implementation of social activity of students has been clarified in the article. The influence of this environment on the professional development of the personality of the future specialist of elementary education, the formation of the social mobility and personal and professional culture are researched. The peculiarities of the organization of the social and educational environment during the training of future teachers of primary education have been considered, its tasks and functions have been substantiated. The attention has been focused on the fact that the socio-educational activity of the university involves not only the creation of certain pedagogical conditions for the student's socialization but also the diagnosis and development of the readiness of future teachers to carry out their professional activities. It has been noted that in order to create a favorable social and educational environment during the professional training of students, it is necessary to adhere to the following requirements: the unity of education, upbringing and development of future teachers of elementary school; awareness of the social significance of the process of education in higher education as the dominant factor in the development of the general cultural potential of the future teacher; formation of professional-value orientations of the future specialist. It has been preconditioned that the social-educational environment in the universities will be effective if its activities are organized according to the corresponding types and directions. As the criteria for the effectiveness of the development of the social and educational environment in the system of training the future teachers of primary schools, its characteristics have been substantiated: liberality, social activity, mobility. The conclusion has been made that the organization of the social and educational environment in higher educational institutions needs to be reformed. In particular, the important directions of improvement of social and educational work at universities have been noticed: provision of social and pedagogical assistance to the individual and professional formation of future specialists of primary education; asserting the health care the life of future teachers as an effective alternative to the spread of destructive trends in the youth environment and an important indicator of the effective activity of educational work in universities.

Keywords: the social and educational environment of the university, the vocational training, the future teachers of elementary school.

П остановка проблеми. Формування національної інтелігенції, сприяння збагаченню іоновленню інтелектуального генофонду нації, виховання ії духовної еліти - основне завдання, що стоїть перед вищими навчальними закладами. Становлення духовно сформованої особистості можливе тільки при збереженні і відродженні духовно-історичних цінностей своєї країни, пріоритетного розвитку культури, науки і освіти як важливих складових прогресу суспільства.

Зосередження уваги науковців на соціальний розвиток майбутніх педагогів зумовлено багатьма факторами: трансформацією соціальнокультурних умов життєдіяльності, посиленням вимог до рівня конкурентоспроможності фахівця 


\section{ВПЛИВ СОЦІАЛЬНО-ВИХОВНОГО СЕРЕДОВИЩА УНІВЕРСИТЕТУ НА ПРОФЕСІЙНУ ПІДГОТОВКУ МАЙБУТНІХ ФАХІВЦІВ ПОЧАТКОВОЇ ОСВІТИ}

в умовах євроінтеграції, необхідністю постійного вдосконалення професійних та особистісних якостей студентської молоді, які спираються, зокрема, на культурне й виховне підгрунтя освітнього процесу в університеті. Відтак, актуалізується значення соціально-виховних впливів на молодого фахівця під час навчання у вищій школі.

Аналіз останніх досліджень і публікацій. Результати проведеного нами аналізу наукової літератури дозволили стверджувати, що для проектування виховного середовища, сприяючого формуванню культури студентів, є достатньо розроблена теоретична база. Встановлено, що предметно-проблемне поле поняття “середовище” визначено у працях А. Калашникова, В. Козирєва, А. Куракіна, С. Моложавого, А. Мудрика, Л. Новікова, В. Семенова та інших. Середовище як чинник формування, розвитку і самореалізації особистості досліджують Н. Боритко, Т. Кліменко, Ю. Мануйлов, Л. Новикова, Н. Сєліванова, І. Фрумін, Н. Щуркова та інші.

Основи сучасного наукового розуміння соціалізаційних процесів студентської молоді закладено в працях А. Рижанової, С. Савченка, О. Севастьянової, С. Шашенко та ін. У психологопедагогічній літературі $є$ чимало досліджень, в яких розглядаються різні аспекти соціальновиховного процесу. Зокрема, у працях І. Беха, Л. Буєвої, Я. Гнутеля, А. Капської, В. Лісовського, Т. Петрової були визначені основні аспекти соціального становлення, динаміки різних сфер життєдіяльності студентської молоді, її проблем в умовах суспільних реформ, ціннісних орієнтацій і поведінкових установок.

Проблеми соціально-освітнього середовища виокремлено в теорії соціальної педагогіки у працях О. Безпалько, Р. Вайноли, І. Звєрєвої, А. Капської, Л.Міщик, Н. Чернухи, Н. Гевчук та інших. Серед досліджень проблем соціальновиховного середовища привертають увагу праці О. Литовченко, Ж. Петрочко, М.Шакурова та ін.; соціально-педагогічного-Ю. Клочан, О. Кузьменко, Н. Максимовської та інших.

Мета статті - обгрунтувати вплив соціальновиховного середовища університету на професійну підготовку майбутніх фахівців початкової освіти.

Виклад основного матеріалу. Нами 3'ясовано, що у науковій літературі напрацьована низка підходів до визначення терміну “соціальновиховне середовище”, під яким традиційно розуміють, по-перше, ознаку соціального середовища, по-друге, сукупність умов життєдіяльності особистості, що цілеспрямовано впливають на її свідомість та поведінку з метою формування певних якостей, переконань, духовноціннісних орієнтацій та потреб, по-третє, конкретний прояв суспільних відносин, який сприяє соціалізації та адаптивності особистості до мінливого середовища, усвідомленню себе людиною, якій близькі та зрозумілі інтереси інших людей, а головні її цінності - загальнолюдські [2].

Окрім означених підходів, у процесі дослідження феномену “соціально-виховне середовище вищого навчального закладу" значимою для нас була і концепція соціальнопедагогічного середовища, розроблена Н. Максимовською, згідно якої “соціальнопедагогічне середовище - це частина загального виховного простору, в якому формується соціальність особистості завдяки цілеспрямованій, науково обгрунтованій і системній соціальнопедагогічній діяльності для ефективного соціального становлення людини, активного перетворення іiї на суб'єкта соціального розвитку самої себе й соціуму [1]. Ми вважаємо, що у контексті проблематики середовища ВН3 феномени “соціально-виховне середовище" та “соціально-педагогічне середовище" (як його трактує Н. Максимовська) є тотожними за структурою системами, які можуть бути співвіднесені як тактичне завдання та стратегічна мета, як проміжне досягнення та кінцевий результат.

Над дослідженням поняттям “соціальновиховне середовище" плідно працюють протягом останніх років багато науковців, оскільки його завданнями $є$ належна професійна підготовка майбутніх фахівців, а також задоволення інтелектуальних, духовних і культурних потреб молодої людини.

Так, “соціально-виховне середовище" тлумачиться як “частина соціокультурного простору, зона взаємодії освітніх систем, їх елементів, освітнього матеріалу і суб'єктів освітніх процесів” [7].

Аналіз педагогічної літератури та практики діяльності Мукачівського державного університету свідчить про те, що саме таке сприятливе соціально-виховне середовище забезпечує формування основних компонентів професійної компетентності: соціально-правової (знання й уміння в галузі взаємодії з суспільними інституціями та іншими людьми, володіння прийомами професійного спілкування i поведінки); спеціальної (готовність до самостійного виконання різних видів діяльності, уміння вирішувати типові професійні задачі й оцінювати результати своєї праці, здатність 


\section{ВПЛИВ СОЦІАЛЬНО-ВИХОВНОГО СЕРЕДОВИЩА УНІВЕРСИТЕТУ НА ПРОФЕСІЙНУ ПІДГОТОВКУ МАЙБУТНІХ ФАХІВЦІВ ПОЧАТКОВОӤ ОСВІТИ}

самостійно здобувати нові знання й уміння за фахом); персональної (здатність до постійного професійного росту і підвищення кваліфікації, а також реалізації себе в професійній праці); компетентності (адекватне уявлення про свої соціально-професійні характеристики і володіння технологіями подолання професійних деструкцій); екстремальної професійної компетентності (здатність діяти в умовах, що раптово ускладнилися, в неординарних обставинах).

На нашу думку, в умовах університету ефективність сприятливого соціально-виховного середовища виявляється насамперед у високому рівні мотивації всіх суб' єктів навчально-виховного процесу, в професійному зростанні студентів. Соціально-виховне середовище ВНЗ забезпечує педагогічну взаємодію суб'єктів навчальновиховного процесу, наукову та соціальногуманітарну діяльність. Показниками позитивного соціально-виховного середовища у ВНЗ як фактора професійно-особистісного становлення майбутнього фахівця є: активність і креативність майбутніх фахівців в оволодінні професійними знаннями, у професійному зростанні та їх включеність у спільну професійну й громадську діяльність, довіра й вимогливість один до одного, поінформованість і суб'єкт-суб'єктна міжособистісна взаємодія всіх учасників педагогічного процесу.

Більшість авторів розглядають соціальновиховне середовище як ознаку соціального середовища чи сукупність умов життєдіяльності особистості, що цілеспрямовано впливають на їі свідомість та поведінку з метою формування певних якостей, переконань, духовно-ціннісних орієнтацій та потреб. Соціально-виховне середовище характеризує конкретний прояв суспільних відносин, який сприяє соціалізації та адаптивності особистості до мінливого середовища, усвідомленню себе людиною, якій близькі та зрозумілі інтереси інших людей, а головні їі цінності - загальнолюдські $[2 ; 4 ; 6 ; 7]$.

Таким чином, думки науковців зводяться до того, що соціально-виховне середовище вищого навчального закладу - це конкретно-історичне середовище, в яке інтегрується соціальновиховний потенціал основних структур простору 3 метою створення найбільш сприятливих умов для індивідуального розвитку студентів, на яких спрямована соціально-виховна дія та активізація. На нашу думку, дане визначення найбільш повно розкриває сутність досліджуваного явища.

Енциклопедія соціальної педагогіки трактує соціальне середовище як складне багаторівневе утворення, конкретний прояв суспільних стосунків, що мають місце в суспільстві, у якому живе та розвивається особистість; сукупність соціальних умов життєдіяльності людини (сфери суспільного життя, соціальні інститути, соціальні групи), які впливають на її свідомість та поведінку [5].

Соціально-педагогічна робота зі студентською молоддю має свої особливості: адаптація студента до умов функціонування вищого навчального закладу (особливо це стосується першокурсника); корекція (захист) відносин між викладацьким складом та молоддю, яка навчається; попередження можливих фізичних, психічних i соціокультурних зіткнень окремого індивіда і груп ризику; розвиток студента як неповторної особистості, формування якості творчого професіонала через процес навчання, виховання, соціалізації. Тому соціально-педагогічна робота у вищих навчальних закладах має адресний характер i повинна враховувати: сфери життєдіяльності студента; актуальні й найтиповіші соціальні та психологічні проблеми молоді; вік, стать, соціальний статус кожного студента; рівень соціальної активності студента та його ставлення до майбутньої професії. Основною метою соціально-виховної роботи у вищому навчальному закладі $є$ формування гармонійно розвиненої, соціально активної, національно свідомої особистості, професійнограмотного, творчого фахівця, який поєднує в собі високі духовність і моральність, професійну компетентність, здатність самостійно та нестандартно мислити, приймати рішення, швидко орієнтуватися у складних обставинах суспільного й особистого життя.

Соціально-виховне середовища у ВНЗ буде ефективно діяти, якщо його діяльність буде організована за такими видами та напрямами:

1) профілактика негативних явищ у студентському середовищі та пропаганда здорового способу життя;

2) соціальна адаптація першокурсників до умов навчання у ВНЗ (подолання соціальнопсихологічних ускладнень різного характеру);

3) формування та розвиток волонтерського руху в університеті, що дає змогу студентам I - II курсів навчатися навичкам соціальної роботи за фахом;

4) соціальна реабілітація, адаптація та супровід студентів з особливими потребами (консультування, допомога у пересуванні, організація соціальної підтримки);

5) культурно-дозвільневий напрямок діяльності соціальної служби як засіб соціальнопсихологічного впливу на студентську молодь 


\section{ВПЛИВ СОЦІАЛЬНО-ВИХОВНОГО СЕРЕДОВИЩА УНІВЕРСИТЕТУ НА ПРОФЕСІЙНУ ПІДГОТОВКУ МАЙБУТНІХ ФАХІВЦІВ ПОЧАТКОВОЇ ОСВІТИ}

(проведення тематичних клубів-кафе, вечорів самодіяльності, відвідування музеїв, театрів, виставок тощо);

6) реалізація екологічного напрямку діяльності (виховання екологічної свідомості молоді шляхом, залучення iї до проведення екологічних акцій у місті та районі);

7) проведення соціального моніторингу i соціальних досліджень у середовищі ВНЗ (бесіди, інтерв'ю, анкетування тощо);

8) здійснення інформаційної діяльності (видання студентської газети, оформлення інформаційних стендів, здійснення соціальної реклами);

9) вирішення проблем працевлаштування (сприяння тимчасовій та сезонній зайнятості студентів).

На думку науковців основними завданнями соціально-виховне середовища у вузі $є$ : надання соціально-педагогічних індивідуальних та групових послуг як засіб підготовки волонтерів, підвищення рівня самосвідомості молоді, оперативного вирішення запитів; надання соціально-інформаційних індивідуальних та групових послуг як засіб пропаганди здорового способу життя, основ репродуктивного здоров'я, прищеплення молоді активної життєвої позиції; надання комплексу послуг як засіб допомоги учасникам навчально-виховного процесу, що перебувають у скрутному становищі, та здійснення соціального супроводу; реалізація державних програм у сфері соціальної роботи зі студентською молоддю з метою поліпшення іiі становища, розв'язання соціальних проблем; надання соціальної, психологічної, правової та інформаційної соціальної допомоги студентській молоді, у тому числі студентам, що є сиротами, інвалідами, молодим студентським сім'ям; сприяння успішній соціальній адаптації студентів до умов навчання у ВН3, особливо першокурсників; профілактика негативних явищ у студентському середовищі [3; 7]

Відповідно до основних завдань соціальновиховне середовище університету здійснювати такі функції:

1) реалізувати проекти, заходи соціального становлення та соціальної підтримки студентської молоді;

2) розробляти пропозиції щодо удосконалення діяльності соціально-виховного середовища, зокрема їх організаційно-правового, науковометодичного, інформаційного, матеріальнотехнічного та фінансового забезпечення;

3) співпрацювати у межах наданих повноважень 3 місцевими органами виконавчої влади, органами місцевого самоврядування, підприємствами, установами та організаціями незалежно від форм їх власності, громадськими організаціями, фізичними особами у вирішенні питань соціального становлення та соціальної підтримки студентської молоді;

4) проводити соціологічні дослідження з метою визначення молодіжних соціальних проблем;

5) здійснювати соціально-психологічне, соціально-педагогічне консультування, надавати інформаційні послуги;

6) сприяти працевлаштуванню студентської молоді;

7) залучати до роботи волонтерів;

8) готувати статистичні, інформаційні матеріали щодо розв'язання актуальних соціальних проблем у студентському середовищі;

Отже, соціально-виховне середовище у ВНЗ це дуже складний і багатогранний процес, цілісна система змістовно-педагогічних та організаційнометодичних заходів, підпорядкованих меті забезпечення готовності майбутнього фахівця дошкільної освіти до професійної діяльності. Результативність такого процесу залежить від певних педагогічних умов, серед яких особливо значущим є співвідношення позиції особистості та системи педагогічних впливів.

Цей процес не може бути стихійним, він передбачає співробітництво, співдіяльність, співтворчість педагога і студента. Цілеспрямованої взаємодії всіх його елементів - учасників освітнього процесу - виникають об'єктивні можливості для актуалізації потреби в саморозвитку, реалізації свого творчого потенціалу й усвідомлення себе як суб’ єктів самозмін.

На основі інтегративного критерію можна виділити кілька часткових критеріїв та їхніх показників для характеристики соціальновиховного середовища. Як критерії ефективності розвитку соціально-виховного середовища в системі багаторівневої підготовки беремо такі параметри: широту, соціальну активність, мобільність такого середовища. Широта соціально-виховного середовища слугує структурно змістовою особливістю, що визначає, які суб' Єкти, об'єкти, процеси та явища містяться в даному середовищі. Показниками цього критерію є різноманітні освітні траєкторії; інтеграція з іншими освітніми закладами, зокрема й на міжнародному рівні; міжвузівський обмін педагогами та студентами; можливості вибору освітніх мікросередовищ, отримання додаткової професійної кваліфікації, можливість вибору викладача тощо. Соціальна активність соціально- 


\section{ВПЛИВ СОЩІАЛЬНО-ВИХОВНОГО СЕРЕДОВИЩА УНІВЕРСИТЕТУ НА ПРОФЕСІЙНУ ПІДГОТОВКУ МАЙБУТНІХ ФАХІВЦІВ ПОЧАТКОВОЇ ОСВІТИ}

виховного середовища $є$ критерієм його соціально орієнтованого потенціалу в середовищі існування. Показниками цього критерію є потреба у випускниках на ринку праці, розвиток у майбутніх професіоналів компетенцій та особистісних якостей. Мобільність соціальновиховного середовища $є$ критерієм його здатності до органічних еволюційних змін у контексті взаємодій із середовищем існування. Передбачається продумана адаптація до суспільних змін, що, з одного боку, враховує нове соціальне замовлення, а з іншого - не спричиняє деструктивні ситуації в освітньому середовищі. Показниками цього критерію можуть бути мобільність цілей, зміст, засоби освіти, кадрового складу [2].

Головною складовою соціально-виховного середовища сучасного вищого навчального закладу $\epsilon$ організація соціально-виховної діяльності, в результаті якої майбутні фахівці засвоюють систему професійних знань, формують практичні уміння та навички застосування цих знань у практичній професійній діяльності. Не менш важливою, на нашу думку складовою соціально-виховного середовища $€$ громадська діяльність, спрямована на залучення майбутніх фахівців до активної участі в житті вишу, міста, держави, формування соціальної мобільності тощо. Взаємозв'язки між названими складовими соціально-виховного середовища ВНЗ, забезпечують динамізм розвитку, цілісність процесу готовності майбутніх фахівців до виконання професійної діяльності у сучасних умовах розвитку суспільства, а також формування їх професійної культури та майстерності [6]. Тому соціально-виховне середовище ВНЗ $є$ простором спільного творчого пошуку шляхів професійного зростання, в якому домінуючими $є$ емоційна, етична, духовна сфери розвитку інтелекту, які інтегруються у професійній культурі особистості.

Висновки і перспективи подальших досліджень. Соціально-виховна робота у ВНЗ потребує формування та впровадження нової концепції, яка має стати основою підготовки студентської молоді до самостійної, активної та творчої життєдіяльності в нових соціальних та культурних умовах, формуванням особистості свідомого громадянина України. Освітня й виховна діяльність навчального закладу повинна знаходитись у тісномувзаємозв' язку, доповнюючи i збагачуючи одна одну. Оновлення змісту загальноосвітніх, соціально-гуманітарних дисциплін повинно бути підпорядковано меті формування в студентів національної самосвідомості, патріотизму, правової i економічної грамотності, соціальної активності, загальної культури особистості, що базується на надбаннях української та світової культури. Перспективи подальших досліджень вбачаємо у висвітленні особливостей діяльності соціальновиховної роботи університету в полікультурному середовищі.

\section{ЛІТЕРАТУРА}

1. Максимовська Н. О. Принципи управління системою анімаційної соціально-педагогічної роботи зі студентською молоддю у сфері дозвілля/ Н. Максимовська //Вісник ЛНУ ІМ. Т. Шевченка 2016. - №1(298) лютий - С.232-240.

2. Манчуленко Л. В. Методика соціально-виховної роботи у сучасних умовах: навчальний посібник для студентів вищих навчальних закладів / Л. Манчуленко. - Чернівці: ЧНУ, 2012. - 239 с.

3. Ольхова Н. В. Експериментальна програма формування світоглядної культури студентів в університетському навчально-виховному середовищі: навчально-методичне видання /Н. Ольхова - Луцьк: Волинський національний університет імені Лесі Українки, 2009. - 174 с.

4. Романюк Л. В. Ціннісні орієнтації студентів: сутність, структура і психологічні механізми розвитку / Л. В. Романюк. - Кам’янець-Подільський: Абетка HOBA, 2004. - 188 c.

5. Соціальна педагогіка: мала енциклопедія / За заг. ред. проф. І.Д. Звєрєвої. - К.: Центр учбової літератури, 2008. - 336 с.

6. Харченко С. Я. Соціалізація дітей та молоді в процесі соціально-педагогічної діяльності: Теорія і практика [Монографія] / С. Харченко. - Луганськ: Альма-Матер, 2006. - 320 с.

7. Штифурак В. Є. Соціально-педагогічні основи організації виховної роботи зі студентською молоддю: монографія / В. Штифурак. - Вінниця: Діло, 2007. -568 c.

\section{REFERENCES}

1. Maksymovska, N. O. (2016). Pryntsypy upravlinnia systemoiu animatsiinoi sotsialnopedahohichnoi roboty zi studentskoiu moloddiu u sferi dozvillia [Principles of managing the system of anthmic and social-pedagogical robotics for young students in the sphere of doses]. Visnyk Lugansk National University im. Tarasa Shevchenka no.1(298), pp.232-240. [in Ukrainian].

2. Manchulenko, L. V. (2012). Metodyka sotsialnovykhovnoi roboty u suchasnykh umovakh: navchalnyi posibnyk dlia studentiv vyshchykh navchalnykh zakladiv [The method of socially-vichivnoi roboty at the time of mentalities]. Chernivtsi: Chernivetsky National University, 239 p. [in Ukrainian].

3. Olkhova, N. V. (2009). Eksperymentalna prohrama formuvannia svitohliadnoi kultury studentiv $v$ universytetskomu navchalno-vykhovnomu seredovyshchi: navchalno-metodychne vydannia [Experimental program of the formation of the students in the university naivalno- 


\section{МЕТОДИКА ЗАСТОСУВАННЯ СУЧАСНИХ МУЛЬТИМЕДІЙНИХ ТЕХНОЛОГІЙ У ПРОЦЕСІ ФОРМУВАННЯ ПРОФЕСІЙНИХ КОМПЕТЕНТНОСТЕЙ МАЙБУТНІХ ПЕДАГОГІВ}

vihovomu seredovische: navchalno-methodical vidanny]. Lutsk: Volynskyi natsionalnyi universytet imeni Lesi Ukrainky, 174 p. [in Ukrainian].

4. Romaniuk, L. V. (2004). Tsinnisni oriientatsii studentiv: sutnist, struktura $i$ psykholohichni mekhanizmy rozvytku [Valuable orientations of students: essence, structure and psychological mechanisms of development]. Kamianets-Podilskyi: Abetka, NOVA, 188 p. [in Ukrainian].

5. Zvierieva, I.D. (Ed.). (2008). Sotsialna pedahohika: mala entsyklopediia [Social pedagogy: small encyclopedia]. Kyiv: Tsentr uchbovoi literatury, 336 p. [in Ukrainian].
6. Kharchenko, S. Ya. (2006). Sotsializatsiia ditei ta molodi $v$ protsesi sotsialno-pedahohichnoi diialnosti: Teoriia i praktyka [Monohrafiia]. [Socialization of children and youth in the process of social and pedagogical activity: Theory and practice]. Luhansk: Alma-Mater, 320 p. [in Ukrainian].

7. Shtyfurak, V. Ye. (2007). Sotsialno-pedahohichni osnovy orhanizatsii vykhovnoi roboty $z i$ studentskoiu moloddiu: monohrafiia [Sociopedagogical bases of organization of educational work with student youth]. Vinnytsia: Dilo, 568 p. [in Ukrainian].

Стаття надійшла до редакції 09.03.2018

УДК 378.011.3-051:004

DOI:

Ольга Потапчук, кандидат педагогічних наук, асистент кафедри комп 'ютерних технологій Тернопільського національного педагогічного університету імені Володимира Гнатюка

\section{МЕТОДИКА ЗАСТОСУВАННЯ СУЧАСНИХ МУЛЬТИМЕДІЙНИХ ТЕХНОЛОГІЙ У ПРОЦЕСІ ФОРМУВАННЯ ПРОФЕСІЙНИХ КОМПЕТЕНТНОСТЕЙ МАЙБУТНІХПЕДАГОГІВ}

У статті розкрито актуальність та особливості застосування сучасних мультимедійних технологій 6 навчальному процесі та йх вплив на формування професійних компетентностей майбутніх педагогів. Виділено основні функції мультимедійних технологій в навчальному процесі та запропоновано основні напрямки методичного використання мультимедійних технологій у проиесі формування професійних компетентностей майбутніх педагогічних фахівців. Встановлено, щзо застосування мультимедійних технологій в навчальному прочесі сприяє раиіональній професійній діяльності викладачів, розширюючи його можллвості, крім того, за умови правильного методичного використання дає можсливість економії часу та інтенсифікаиії педагогічного процесу.

Ключові слова: мультимедійні технології, навчальний процес, педагогічні фахівці, інформатизація, професійні компетентності.

Puc. 1. Лim. 5.

Olga Potapchuk, Ph.D.(Pedagogy), assistant of the Computer Technologies Department Ternopil Volodymyr Hnatyuk National Pedagogical University

\section{METHODOLOGY OFAPPLICATIONOFMODERN MULTIMEDIATECHNOLOGIES IS IN THE PROCESS OF FORMING OF PROFESSIONAL COMPETENCE OF FUTURE TEACHERS}

In the article actuality and features of application of modern multimedia technologies in an educational process and their influence are exposed on forming of professional competence of future teachers. The basic functions of multimedia technologies are distinguished in an educational process (recreation of educational information, design, self-education, audiocommunicative, visual) and basic directions of the methodical use of multimedia technologies are offered in the process of forming of professional competence of future pedagogical specialists. Application of multimedia technologies in the process of forming of professional competence of future teacher stakes place for providing of concrete aims: abstracting, explanation and generalizations that are the basic criteria of studies. It is set that application of multimedia technologies in an educational process assists rational professional activity of teachers, extending him to possibility, in addition, on condition of the correct methodical use gives an opportunity to the economy of time and intensification of pedagogical process. However, at the choice of means of multimedia technologies it is necessary to take into account the features of concrete educational discipline, her conformities to law and research methods, and that modern multimedia technologies are effective only in combination with traditional facilities and methods of studies.

Keywords: multimedia technologies, educational process, pedagogical specialists, informatization, are professional competence.

П

остановка проблеми. На сучасному етапі розвитку інноваційних технологій, для успішного соціального розвитку суспільства, система освіти в Україні повинна буги спроможна готувати висококваліфікованих фахівців, які відповідатимуть вимогам інформаційного суспільства та будугь конкуренто-спроможними на сучасному ринку праці. Умови розвитку засобів 